\title{
AUDIT TEKNOLOGI INFORMASI MENGGUNAKAN COBIT 5 DOMAIN BUILD ACQUIRE IMPLEMENT PADA PT BEIERSDORF INDONESIA
}

\author{
Taufik Hidayat ${ }^{1}$, Cahyani Budihartanti ${ }^{2}$ \\ Sistem Informasi, Universitas Nusa Mandiri ${ }^{1,2}$ \\ e-mail: taufikofficials@gmail.com,cahyani.cbh@nusamandiri.ac.id,
}

Received: October 07, 2021, Revised: October 15, 2021 Accepted: October 20, 2021

\begin{abstract}
Abstrak
PT. Beiersdorf Indonesia merupakan perushaan FMCG multi nasional yang bergerak dalam kategori perawatan kulit. Dalam operasional perusahaan dalam rangka mengakselerasi dan memonitor penjualan menggunakan aplikasi DAR \& BFAST. DAR \& BFAST adalah sistem aplikasi yang mendukung proses bisnis dengan fungsinya memonitor aktifitas SPG \& Salesman. Masalah yang dihadapi adalah perlunya evaluasi dengan melakukan penilaian tata kelola dan manajemen TI untuk mengetahui kondisi TI saat ini dan pemahaman mengenai kemampuan untuk mencapai tujuan bisnisnya. Penelitian ini akan berfokus pada penilaian kapabilitas proses tata kelola dan manajemen TI pada domain BAI COBIT versi 5 dengan berfokus pada domain proses BAI02 dalam rangka untuk menilai kapabilitas proses terkait pengelolaan pendefinisian kebutuhan dari implementasi DAR \& BFAST. Metode penelitian yang digunakan adalah memakai framework penilaian yang mengacu pada COBIT (Control Objective for Information and Related Technology) versi 5. Terdapat Process Assessment Model (PAM) pada framework ini untuk menentukan tingkat efektifitas dan efisiensi dari sekumpulan proses, dengan cara mengevaluasi tingkat kematangan kapabilitasnya. Metode pengumpulan data pada penelitian ini adalah dengan menyebarkan kuesioner dan wawancara ke pihak penanggung jawab prosesproses yang ada. Hasil penilaian implementasi TI berbasis COBIT versi 5 di PT Beiersdorf Indonesia Indonesia menunjukkan tingkat kapabilitas proses TI domain proses BAI02 berada pada level 1 (Performed) dengan skala $24 \%$ dengan tingkat pencapaian P (partially achieved). Rekomendasi perbaikan disusun untuk mencapai target tingkat kapabilitas yang diharapkan.
\end{abstract}

Kata kunci: Penilaian kapabilitas proses tata kelola dan manajemen TI, COBIT 5

\begin{abstract}
PT. Beiersdorf Indonesia is a multi-national FMCG company engaged in the skin care category. In the company's operations in order to accelerate and monitor sales using the DAR \& BFAST application. DAR \& BFAST is an application system that supports business processes with the function of monitoring SPG \& Salesman activities. The problem faced is the need for evaluation by conducting an assessment of IT governance and management to determine the current state of IT and an understanding of its ability to achieve its business goals. This study will focus on assessing the capability of IT governance and management processes in the BAI COBIT version 5 domain by focusing on the BAIO2 process domain in order to assess the process capabilities related to the management of defining requirements from the implementation of DAR \& BFAST. The research method used is to use an assessment framework that refers to COBIT (Control Objective for Information and Related Technology) version 5. There is a Process Assessment Model (PAM) in this framework to determine the level of effectiveness and efficiency of a set of processes, by evaluating the maturity level of its capabilities. . The method of data collection in this research is by distributing questionnaires and interviews to the party in charge of the existing processes. The results of the COBIT version 5-based IT implementation assessment at PT Beiersdorf Indonesia Indonesia show the Capability Level of the BAIO2 process domain IT process is at level 1
\end{abstract}


https://jurnal.amikwidyaloka.ac.id/index.php/awl jurnal@amikwidyaloka.ac.id / editor.jurnalwidya@gmail.com

(Performed) with a scale of $24 \%$ with an achievement level of $P$ (partially achieved). Recommendations for improvement are prepared to achieve the expected capability level target.

Keywords: Assessment of IT governance and management process capability, COBIT 5.

\section{$1 \quad$ Pendahuluan (or Introduction)}

PT Beiersdorf adalah perusahaan perawatan kulit global yang berbasis di Hamburg, Jerman. PT Beiersdorf telah terdaftar di DAX sejak Desember 2008 dan memliki brand Nivea yang merupakan salah satu merek perawatan kulit terbesar di dunia. PT Beiersdorf memiliki lebih dari 130 tahun pengalaman perawatan kulit dan dikenal dengan produk inovatif dan berkualitas tinggi. Di Indonesia sendiri PT Beiersdorf memasarkan 2 brand yaitu Nivea \& Hansaplast [1].

Dalam operasional bisnis PT Beiersdorf tentu tidak akan terlepas dari keterkaitannya dengan penggunaan teknologi informasi (TI) termasuk bagian penjualan atau distribusi. Kehadiran teknologi informasi dalam operasional bisnis PT Beiersdorf tentunya diharapkan memberikan beragam manfaat bagi para penggunanya, mulai dari efisiensi, transaparansi, efektifitas, maupun dalam hal pengambilan keputusan akan lebih cepat dengan dibantu diterapkannya teknologi informasi.

Proyek teknologi informasi yang saat ini berjalan dalam rangka menunjang otomatisasi proses, monitoring \& reporting di PT Beiersdorf adalah sistem Daily Activity Report (DAR) yang digunakan untuk monitoring kinerja tim penjualan \& sistem Beiersdorf Frontliner Automation System (BFAST) yang digunakan untuk memonitor kinerja dari Nivea Beauty Consultant (NBC).

Permasalahan yang ada dalam proyek tersebut adalah belum adanya suatu sistem tata kelola terstandar yang baik dalam pengelolaan perangkat dan implementasi proyek DAR \& BFAST sehingga akan sulit dalam penanganan permasalahan pada implementasi dan penggunaan sistem tersebut.

Dengan berangkat dari kesadaran bahwa penggunaan sistem DAR \& BFAST dalam operasional bisnis PT Beiersdorf akan menambahkan nilai posistif bagi perusahaan dan untuk setiap investasi perlu diukur atau diketahui tingkat efektifitas dan efisiensi yang dihasilkan maka diperlukan adanya sebuah audit teknologi inoformasi.

Dalam melakukan audit tentunya dibutuhkan sebuah framework dan salah satu framework yang peneliti anggap tepat untuk melakukan audit ini adalah COBIT. Versi COBIT yang digunakan adalah COBIT versi 5 karena memiliki keunggulan dibanding versi lainnya. Keunggulannya adalah COBIT 5 memiliki 5 prinsip dasar untuk tata kelola teknologi informasi dari organisasi atau perusahaan yang terdiri dari memenuhi kebutuhan stakeholder, end to end supporting, integrated framework implementation, holistic approach activation \& memisahkan tata kelola dari manajemen [2]. Meninjau dari latar belakang yang ada, maka dapat diidentifikasikan 2 permasalahan berikut. Yaitu pertama dimana belum adanya standarisasi atau kebijakan dalam hal implementasi proyek DAR \& BFAST dan yang kedua belum adanya evaluasi tata kelola TI dalam dalam proyek DAR dan BFAST yang berdampak kepada pengelolaan dan implementasi TI yang kurang efektif dan efisien. Dari masalah tersebut, maka penulis bermaksud melakukan penelitian evaluasi proyek DAR \& BFAST dalam rangka mengetahui tingkat kapabilitas saat ini dan memberikan rekomendasi untuk meningkatkan capability level yang ada dimana scope nya pada Domain BAI02 dengan berfokus pada pendefinisian kebutuhan.

\section{Tinjauan Literatur (or Literature Review)}

Abdul Hakim, Hoka Saragih, Agus Suharto menjelaskan dalam Perkembangan TI saat ini sudah menjadi kebutuhan yang sangat penting bagi hampir semua organisasi perusahaan baik pemerintahan maupun swasta sebagai penunjang dalam meningkatkan efektifitas dan efisiensi proses kinerja, untuk mencapai hal tersebut diperlukan suatu pengelolaan TI yang baik dan benar, sehingga keberadaan TI dirasakan termanfaatakan oleh organisasi [3].

Johanes Andry menjelaskan pengelolaan teknologi informasi saat ini bukan lagi dipandang sebagai unsur pendukung proses bisnis tetapi sudah dipandang sebagai bagian dari strategi bisnis [4].

Susanti Purwaningsih menjelaskan kunci suksesnya implementasi sistem informasi diukur dari kualitas sistem, kualitas informasi, kualitas pelayanan dan kepuasan pengguna. Jika implementasi sistem informasi tidak terkelola dengan baik, tidak ada standarisasi dan sulit dalam penanganan permasalahan maka akan berpengaruh terhadap kualitas sistem, kualitas informasi, kualitas pelayanan dan kepuasan pengguna dan berakibat pada buruknya kualitas pelaksanaan proyek sistem informasi tersebut[5]. 
Penelitian-penelitian tersebut terbukti berhasil memberikan solusi dan rekomendasi berdasarkan evaluasi yang dilakukan untuk peningkatan capability level sehingga implementasi TI yang ada bisa dilaksanakan lebih baik lagi dan tingkat kesuksesan implementasi TI lebih terstandarisasi baik dalam hal prosedur, kebijakan maupun pengelolaan aset yang ada.

\section{Metode Penelitian (or Research Method)}

\subsection{Tahapan Penelitian}

Dalam melaksanakan kegiatan penelitian di PT Beiersdorf menggunakan tahapan seperti yang ditunjukkan diagram alir berikut:

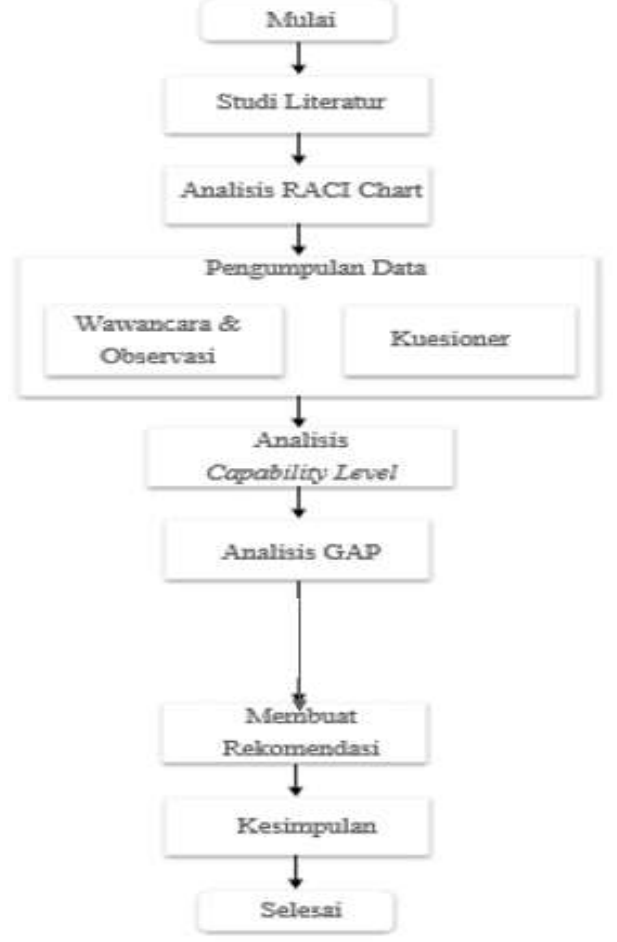

Berikut Penjelasan dari setiap tahapan:

\section{Gambar 1 Tahapan Penelitian}

1. Melakukan studi literatur tentang COBIT 5 terutama domain BAI dan menggali informasi terkait profil, organisasi dan sejarah PT Beiersdorf Indonesia

2. Menentukan subjek dan objek penelitian di PT Beiersdorf

3. Menentukan responden yang akan mengisi kuesioner berdasarkan RACI Chart.

4. Melakukan wawancara dan observasi di departemen SSD dan pengambilan data dengan menggunakan kuesioner kepada responden yang sudah ditentukan.

5. Mengevaluasi dan menganalisis data dari kuesioner yang telah diisi.

6. Membuat rekomendasi dan kesimpulan dari hasil evaluasi

\subsection{Instrument Penelitian}

Instrumen penelitian merupakan alat yang dipergunakan untuk mengumpulkan data. Dalam penelitian di PT Beiersdorf ini, instrumen yang digunakan berupa kuesioner yang terdiri dari pertanyaan-pertanyaan berdasarkan standar dari COBIT 5 [2]. Pertanyaan-pertanyaan tersebut diberikan kepada responden yang berjumlah 10 orang yaitu member dari departemen Sales Support \& Development di PT Beiersdorf dimana responden tersebut terlibat dalam tata kelola proyek DAR \& BFAST. 
Volume 2, Nomor 2,Oktober 2021: halaman 189-197

https://jurnal.amikwidyaloka.ac.id/index.php/awl jurnal@amikwidyaloka.ac.id / editor.jurnalwidya@gmail.com

Tabel 1 Contoh Lembar Kerja Evaluasi (Kuesioner)

\begin{tabular}{|c|c|c|c|c|c|c|c|c|}
\hline \multirow{2}{*}{\multicolumn{3}{|c|}{ Nama Responden }} & & & & & & \\
\hline \multicolumn{8}{|c|}{ Jabatan Responden } & \\
\hline BAI-01 & \multicolumn{8}{|c|}{ Mengelola Program dan Proyek } \\
\hline \multirow[t]{2}{*}{ Tujuan } & \multicolumn{8}{|c|}{$\ldots$} \\
\hline & $\ldots$ & Kriteria & $\begin{array}{c}\text { Sesuai } \\
\text { Kriteria } \\
\text { Y/T }\end{array}$ & $\begin{array}{c}\mathrm{N} \\
(0- \\
15 \%)\end{array}$ & $\begin{array}{c}P \\
(>15- \\
50 \%)\end{array}$ & $\begin{array}{c}\mathrm{L} \\
(>50- \\
85 \%)\end{array}$ & $\begin{array}{c}F \\
(>85- \\
100 \%)\end{array}$ & $\begin{array}{c}\text { Dokumen } \\
\text { Terkait }\end{array}$ \\
\hline \multicolumn{9}{|l|}{ Level 0} \\
\hline \multirow[t]{3}{*}{ Level 1} & \multirow[t]{3}{*}{ PA 1.1} & BAI01.01 & & & & & & \\
\hline & & BAI01.02 & & & & & & \\
\hline & & BAI01.03 & & & & & & \\
\hline \multirow[t]{2}{*}{ Level 2} & PA 2.1 & & & & & & & \\
\hline & PA 2.2 & & & & & & & \\
\hline \multirow[t]{2}{*}{ Level 3} & PA 3.1 & & & & & & & \\
\hline & PA 3.2 & & & & & & & \\
\hline \multirow[t]{2}{*}{ Level 4} & PA 4.1 & & & & & & & \\
\hline & PA 4.2 & & & & & & & \\
\hline \multirow[t]{2}{*}{ Level 5} & PA 5.1 & & & & & & & \\
\hline & PA 5.1 & & & & & & & \\
\hline
\end{tabular}

Jika kriteria pada capability level tersebut sesuai, maka responden mengisi dengan huruf $\mathrm{Y}$ dan mengisi kategori pencapaian dari kriteria tersebut di salah satu kolom N, P, L atau F. Responden juga dapat mengisi nama dokumen berkaitan dari kriteria yang ditanyakan. Setelah semua pertanyaan dalam kuesioner dijawab oleh responden, maka hasilnya dirangkum pada tabel detail penilaian capability level sebuah proses di tabel 2 berikut.

Tabel 2 Detail Penilaian Capability Level Proses

\begin{tabular}{|c|c|c|c|c|c|c|c|c|c|c|}
\hline $\begin{array}{l}\text { Nama } \\
\text { Proses }\end{array}$ & Level 0 & Level 1 & Lev & el 2 & Lev & & & & & \\
\hline BAI01 & & $\begin{array}{l}\text { PA } \\
1.1\end{array}$ & $\begin{array}{l}\text { PA } \\
2.1\end{array}$ & $\begin{array}{l}\text { PA } \\
2.2\end{array}$ & $\begin{array}{l}\text { PA } \\
3.1\end{array}$ & $\begin{array}{l}\text { PA } \\
3.2\end{array}$ & $\begin{array}{l}\text { PA } \\
4.1\end{array}$ & $\begin{array}{l}\text { PA } \\
4.2\end{array}$ & $\begin{array}{l}\text { PA } \\
5.1\end{array}$ & $\begin{array}{l}\text { PA } \\
5.2\end{array}$ \\
\hline $\begin{array}{l}\text { Penilaian } \\
\text { Kriteria }\end{array}$ & & & & & & & & & & \\
\hline $\begin{array}{l}\text { Pencapaian } \\
\text { Capability } \\
\text { Level }\end{array}$ & & & & & & & & & & \\
\hline
\end{tabular}

Tabel 2 di atas dipergunakan untuk merangkum jawaban kuesioner yang diisi oleh responden untuk setiap proses. Didalam baris Penilaian Kriteria diisi dengan skala penilaian dalam inisial huruf N, P, L atau F sesuai dengan jawaban kuesioner. Pada baris Pencapaian capability level diisi angka 0-5 sesuai dengan tingkat capability level yang dicapai. Sedangkan Tabel 3 dibawah digunakan untuk meringkas penilaian capability level dari seluruh proses [2].

Tabel 3 Contoh Ringkasan Penilaian Capability Level Proses

\begin{tabular}{|c|c|c|c|c|c|c|c|c|c|c|}
\hline \multicolumn{11}{|c|}{ Process Assessment Results } \\
\hline \multirow{2}{*}{ Nama Proses } & \multirow{2}{*}{$\begin{array}{l}\text { Level } \\
\text { Target }\end{array}$} & \multicolumn{6}{|c|}{ Process Capability Level } & \multirow{2}{*}{$\begin{array}{c}\text { Total } \\
\text { Responden }\end{array}$} & \multirow[t]{2}{*}{$\begin{array}{l}\text { Total } \\
\text { Bobot } \\
\end{array}$} & \multirow{2}{*}{$\begin{array}{c}\text { Capability } \\
\text { Level }\end{array}$} \\
\hline & & 0 & 1 & 2 & 3 & 4 & 5 & & & \\
\hline \multicolumn{11}{|c|}{ Build, Acquire and Implement } \\
\hline $\begin{array}{l}\text { BAI02 - } \\
\text { Mengelola } \\
\text { Program \& } \\
\text { Proyek }\end{array}$ & & & & & & & & & & \\
\hline
\end{tabular}


Tabel 3 di atas dipergunakan untuk merangkum process capability level dari kuesioner yang diisi oleh semua responden untuk setiap proses. Kolom Level Target diisi dengan level target yang diharapkan dimana ditentukannya dari melihat level sekarang dengan level yang sedang dituju atau tingkatan berikutnya. Kolom process capability level dimana terdapat sub-kolom angka 0 sampai 5 diisi dengan jumlah responden yang mendapatkan hasil dilevel tersebut. Kolom Total Responden diisi dengan akumulasi atau jumlah semua responden yang melakukan pengisisan kuoesioner. Kolom Total Bobot disi berdasarkan perhitungan rata-rata antara process capability level yang di dapat dengan jumlah respondennya. Capability level diisi sesuai hasil pemilihan level yang didapat dengan melihat jumlah responden terbanyak.

\subsection{Metode Pengumpulan Data, Populasi dan Sampel Penelitian}

\subsubsection{Metode Pengumpula Data}

Data yang digunakan untuk penelitian adalah data yang bisa memberikan gambaran kondisi tata kelola TI saat ini dimana hal tersebut didapatkan dari pengisian kuesioner dan wawancara.

1. Kuesioner

Kuesioner yang digunakan dalam penelitian ini adalah kuesioner dimana tujuannya mengukur capability level dan data kuesioner didapatkan dengan cara membagikan kuesioner kepada responden dari departemen SSD yang dijadikan sebagai sampel penelitian [2].

2. Wawancara

Data wawancara didapatkan peneliti dengan melakukan kunjungan langsung ke unit kerja yang akan diaudit guna mewawancarai narasumber terkait dimana narasumber tersebut adalah bapak Frans Bago dari tim data analyst sebagai penanggung jawab dari proyek DAR dan bapak Ibnu Fajar dari tim winning in store sebagai penanggung jawab proyek BFAST. Pertanyaan yang diajukan sesuai dengan referensi COBIT 5 dengan berfokus sesuai domain yang digunakan dalam penelitian yaitu BAI02 [2]. Jawaban dari responden tidak dibatasi, responden dihindarkan dari jawaban ya atau tidak melainkan menjelaskan apa yang tanyakan. Pertanyaan disampaikan kepada responden secara acak dan terdapat beberapa pertanyaan yang dikembangkan yang disebabkan dari jawaban responden tersebut [6]. Dalam proses wawancara responden sedikit diberi gambaran dan penjelasan mengenai evaluasi implementasi proyek DAR \& BFAST sehingga jawaban responden tidak jauh dari objek penelitian.

\subsubsection{Populasi}

Dalam penelitian ini populasi [7] yang dimaksud adalah anggota dari departemen SSD dimana total anggota berjumlah 15 orang.

Tabel 4 Populasi Pegawai departemen SSD

\begin{tabular}{|lc|}
\hline \multicolumn{1}{|c|}{ Sub-Departemen SSD } & Jumlah Pegawai \\
\hline Capabilty \& Training & 2 \\
\hline Winning \& Store & 3 \\
\hline Distributor Trade Development & 7 \\
\hline Route To Market & 3 \\
\hline \multicolumn{2}{|c|}{ Total } \\
\hline
\end{tabular}

\subsubsection{Sampel}

Dari total populasi pegawai di departemen SSD yang berjumlah 15 orang dipilih hanya 5 pegawai sebagai responden dimana memiliki tugas dan tanggung jawab dalam obyek penelitian [7]. Berikut adalah responden yang menerima kuesioner:

Tabel 5 Sampel Populasi

\begin{tabular}{|lcc|}
\hline \multicolumn{1}{|c|}{ Sub-Departemen SSD } & Jumlah Pegawai & Responden \\
\hline Capabilty \& Training & 2 & 0 \\
\hline Winning \& Store & 3 & 2 \\
\hline
\end{tabular}

2

JURNAL WIDYA This work is licensed under a Creative Commons Attribution-NonCommercialShareAlike 4.0 International License. 
Volume 2, Nomor 2,Oktober 2021: halaman 189-197

https://jurnal.amikwidyaloka.ac.id/index.php/awl

jurnal@amikwidyaloka.ac.id / editor.jurnalwidya@gmail.com

\begin{tabular}{|ccc|}
\hline Distributor Trade Development & 7 & 2 \\
\hline Route To Market & 3 & 1 \\
\hline Total & $\mathbf{1 5}$ & $\mathbf{5}$ \\
\hline
\end{tabular}

Sampel dari populasi yang berjumlah 5 orang tersebut akan diminta untuk mengisi kuesioner dimana isi dari lembar kuesioner berupa identitas responden seperti nama \& jabatan, petunjuk pengisian dan tabel pertanyaan. Setelah kuesioner yang di sebar sudah terisi lalu akan divalidasi terlebih dahulu, apabila data kuesioner terdapat sesuatu yang tidak valid maka kuesioner yang tidak valid akan diulang kembali sampai seterusnya menghasilkan hasil yang valid. Data hasil pengisian kuesioner dari semua responden akan dikumpulkan dan diolah hingga didapatkan sebuah gambaran kondisi tata kelola TI saat ini.

\subsection{Metode Analisis Data}

Beberapa metode analisis yang digunakan peneliti dalam melakukan analisa adalah sebagai berikut:

1. Analisis Capability Level

Capability Level setiap proses yang dinilai dinyatakan dalam level 0 sampai 5. Level 0 berarti proses tidak terimplementasi, Level 1 berarti proses yang terimplementasi telah mencapai tujuan prosesnya., Level 2 berarti proses telah diimplementasikan secara berhasil dalam artian terencana, terawasi dan disesuaikan serta produk kerjanya telah terbentuk, terkendali dan terpelihara, Level 3 berarti proses diimplementasikan menggunakan proses yang telah terdefinisi yang mampu untuk mencapai keluaran prosesnya, Level 4 berarti proses dioperasikan dalam batasan yang terdefinisi untuk mencapai keluaran prosesnya dan Level 5 berarti proses secara berkelanjutan ditingkatkan untuk memenuhi tujuan bisnisnya [2].

\section{Analsis kesenjangan atau GAP}

Analisis GAP dilakukan untuk mendefinisikan kesenjangan antara tingkat capability level aktual dengan tingkat kematangan yang diharapkan dan menerjemahkan gap tersebut menjadi peluang untuk perbaikan. Untuk memperoleh GAP dengan cara menganalisa hasil antara kondisi sekarang dengan targetnya. Kondisi sekarang didapat dari data yang diperoleh melalui kuesioner dan wawancara, kemudian target ditentukan dengan level yang sedang dituju dari level yang di dapat sekarang. Cara perhitungan yang digunakan untuk mendapatkan GAP adalah level target dikurangi dengan kondisi sekarang. Berikut cara perhitungannya [2]:

-Nilai GAP = Level Target - Level Sekarang

-Niali GAP : Nilai Kesenjangan antara kondisi sekarang dengan target yang dituju.

-Level Target : Level yang akan dituju

-Level Sekarang : Level yang didapat dari hasil penelitian sekarang

\section{$4 \quad$ Hasil dan Pembahasan (or Results and Analysis)}

\subsection{Analisis RACI Chart}

Berikut adalah tabel perhitungan diagram RACI berdasarkan masing-masing proses.

Tabel 6 RACI Chart

\begin{tabular}{|lc|c|c|c|c|c|c|c|c|c|}
\hline & BA & BA & BA & BA & BA & BA & BA & BA & BA & BA \\
\hline \multicolumn{1}{|c|}{ Sub-Departemen SSD } & I 01 & I 02 & I 03 & I 04 & I 05 & I 06 & I 07 & I 08 & I & I 10 \\
\hline Capabilty \& Training & & & & & & & & & & \\
\hline Winning \& Store & R & C & R & R & R & R & A & R & C & C \\
\hline Distributor Trade Development & C & R & R & C & A & I & R & C & R & I \\
\hline Route To Market & A & A & A & C & C & A & C & I & A & A \\
\hline
\end{tabular}

Berdasarkan dari Tabel 6 di atas sudah ditentukan responden yang berkompeten untuk mengisi Kuesioner adalah Winning In Store, Distributor Trade \& Development \& Route To Market. 


\subsection{Analisis \& Perhitungan Capability Level}

Berdasarkan hasil dari kuesioner yang telah diisi oleh 5 responden dan wawancara serta observasi yang dilakukan, maka dapat disimpulkan bahwa hasil dari Capability Level domain BAI02 berada pada level. Tabel 7 menunjukan keseluruhan jawaban kuesioner dari responden.

Tabel 7 Ringkasan Hasil Pencapaian Capability Level

\begin{tabular}{|c|c|c|}
\hline List Responden & Level & Criteria \\
\hline Responden 1 & 1 & $29 \%$ \\
\hline Responden 2 & 1 & $16 \%$ \\
\hline Responden 3 & 1 & $38 \%$ \\
\hline Responden 4 & 1 & $16 \%$ \\
\hline Responden 5 & 1 & $20 \%$ \\
\hline Average & 1 & $\mathbf{2 4 \%}$ \\
\hline
\end{tabular}

Tabel 8 Ringkasan Penilaian Capability Level Proses

\begin{tabular}{|l|c|c|c|c|c|c|c|c|c|c|c|}
\hline Process Assessment Results \\
\hline \multirow{2}{*}{ Nama Proses } & $\begin{array}{c}\text { Level } \\
\text { Target }\end{array}$ & \multicolumn{6}{|c|}{$\begin{array}{c}\text { Process Capability } \\
\text { Level }\end{array}$} & $\begin{array}{c}\text { Total } \\
\text { Responden }\end{array}$ & $\begin{array}{c}\text { Total } \\
\text { Bobot }\end{array}$ & $\begin{array}{c}\text { Capability } \\
\text { Level }\end{array}$ \\
\cline { 3 - 10 } & 0 & 1 & 2 & 3 & 4 & 5 & & & \\
\hline BAI & 2 & & 5 & & & & & 5 & 5 & 1 \\
\hline
\end{tabular}

Tabel 8 di atas menunjukkan ringkasan penilaian Capability Level dari jawaban kuesioner oleh 5 responden terpilih. Didapatkan hasil Capability Level untuk proses BAI 02 berada pada level 1 yaitu Performed. Kuesioner yang telah diisi juga divalidasi dengan melakukan wawancara serta observasi untuk mengumpulkan informasi pendukung terkait domain proses BAI 02.

Berdasakan hasil wawancara juga didapati bahwa level yang ingin dicapai adalah naik satu tingkat dari nilai yang sudah ada pada setiap domain prosesnya. Tabel 9 menunjukan bahwa hasil Capability Level adalah bernilai 1 dan level yang ingin dicapai adalah 2 .

Tabel 9 Analisis Gap Domain Proses

\begin{tabular}{|c|c|c|c|}
\hline Nama Proses & $\begin{array}{c}\text { Level saat } \\
\text { ini }\end{array}$ & $\begin{array}{c}\text { Level } \\
\text { Target }\end{array}$ & Gap \\
\hline BAI 02 & 1 & 2 & 1 \\
\hline
\end{tabular}

Dari

hasil penilaian yang dilakukan pada domain BAI02 diperoleh hasil penilaian pada tingkat pencapaian Partially Achieved (Tercapai sebagian) dengan capability scoring 24\% sehingga capability domain level proses BAI01 berada pada level 1 (performed). Aktifitas dan Dokumen yang saat ini belum dilakukan pada domain BAI02 oleh PT. Beiersdorf Indonesia dapat dilihat pada Tabel 10 dan 11 dibawah.

Tabel 9 Best Practice BAI 02

JURNAL WIDYA This work is licensed under a Creative Commons Attribution-NonCommercialShareAlike 4.0 International License. 


\begin{tabular}{|l|l|}
\hline No & \multicolumn{1}{|c|}{ Aktifitas (Best Practice) BAI02 } \\
\hline BAI02.01 Mendefenisikan dan Memelihara fungsi dan kebutuhan teknis bisnis \\
\hline 1. & $\begin{array}{l}\text { Mendefenisikan dan mengimplementasikan defenisi kebutuhan, prosedur pemeliharaan serta } \\
\text { repositori kebutuhan yang sesuai untuk ukuran, kompleksitas, tujuan, dan risiko dari inisiatif yang } \\
\text { sedang dipertimbangkan perusahaan. }\end{array}$ \\
\hline 2. & $\begin{array}{l}\text { Menyampaikan bisnis requirement dalam hal kesenjangan antara kemampuan bisnis saat ini dan } \\
\text { yangdiinginkan perlu untuk ditangani dan bagaimana juga akan berinteraksi dengan solusi dan } \\
\text { solusi tersebut digunakan. }\end{array}$ \\
\hline \multicolumn{2}{|c|}{ BAI02.02 Menjalankan kelayakan studi dan merumuskan alternatif solusi } \\
\hline 3. & $\begin{array}{l}\text { Menentukan dan melaksanakan kelayakan studi, termasuk panduannya dengan dasar yang jelas, } \\
\text { ringkas juga menjelaskan solusi alternatif yang akan memenuhi requirement bisnis. }\end{array}$ \\
\hline
\end{tabular}

Tabel 10 Work Document BAI 02

\begin{tabular}{|l|l|}
\hline No & \multicolumn{1}{|c|}{ Dokumen (Work Product) BAI02 } \\
\hline BAI02.01 Mendefenisikan dan Memelihara fungsi bisnis dan kebutuhan teknis \\
\hline 1 & Vendor RFIs (Request For Information) and RFPs (Request For Proposal) \\
\hline BAI02 & .02 Menjalankan studi kelayakan dan merumuskan solusi alternatif \\
\hline 2 & Katalog Vendor \\
\hline 3 & $\begin{array}{l}\text { Hasil keputusan evaluasi vendor ; RFI and RFP (Request for Proposal) evaluations; Vendor RFls } \\
\text { and RFPs }\end{array}$ \\
\hline BAI02.03 Mengelola risiko kebutuhan (requirement risk) \\
\hline 4 & Aksi Mitigasi risiko \\
\hline BAI02.04 Mendapatkan persetujuan kebutuhan dan solusi \\
\hline 5 & Persetujuan stakeholder mengenai requirement dan solusi yang diusulkan \\
\hline
\end{tabular}

Untuk meningkatkan skala hingga pada pencapaian target perlu pendokumentasian dokumen diatas yang belum ada tersebut untuk pencapaian level 1 hingga lanjut ke penilaian level 2 kemudian.

Menurut hasil perhitungan saat ini PT Beiersdorf telah melakukan pendefenisian dan pemeliharaan fungsi bisnis dan kebutuhan teknis namun belum mendefenisikan dan mengimplementasikan defenisi kebutuhan, prosedur pemeliharaan serta repositori kebutuhan yang sesuai, belum dapat menyampaikan kebutuhan bisnis untuk mengatasi kesenjangan terkait kemampuan bisnis dan belum ada dokumentasi Vendor RFIs (Request For Information) and RFPs (Request For Proposal) dari Vendor. Telah mampu mempertimbangkan kebutuhan dari resiko dengan baik namun belum menghasilkan dokumentasi aksi mitigasi risiko. Telah mampu mendapatkan persetujuan kebutuhan dan solusi sudah dilakukan dengan cukup baik namun belum ada dokumentasi persetujuan stakeholder mengenai requirement dan solusi yang diusulkan.

Namun dalam proses menjalankan studi kelayakan dan merumuskan solusi alternatif terkait pendefenisian kebutuhan TI harus lebih dioptimalkan lagi karena belum melakukan penentuan dan pelaksanaan studi kelayakan, panduan atau solusi kerja dasar yang sangat jelas dan ringkas dimana menjelaskan solusi alternatif. Belum juga harus dilakukan evaluasi vendor terkait kebutuhan-kebutuhan TI perusahaan.

\section{$5 \quad$ Kesimpulan (or Conclusion)}

Berdasarkan dari hasil penelitian dan analisis yang sudah dilakukan pada tata kelola teknologi informasi menggunakan framework COBIT 5 domain BAI (Build, Acquire and Implement) pada proses BAI02 yaitu mengelola pendefinisian kebutuhan dan evaluasi dilakukan dengan cara melakukan penyebaran dan pengisian kuesioner kepada 5 orang responden maka dapat diambil disimpulkan tingkat kapabilitas dari hasil evaluasi domain BAI pada proses BAI02 berada pada level 1 yaitu performed process. Hasil tersebut menunjukan proses

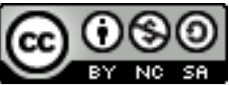


terimplementasi sudah mencapai tujuan prosesnya, dalam artian sudah dilakukan namun belum ada manajemennya. Target level kapabilitas tata kelola dan manajemen TI berada di level 2 dimana saat ini belum tercapai.

\section{Referensi (Reference)}

[1] Beiersdorf AG, “Company FAQ | Beiersdorf,” 2021. https://www.beiersdorf.com/metapages/faq/company\#: :text=Beiersdorf $\mathrm{AG}$ is a global,world's largest skin care brands.\&text=Other names in its successful,Labello\%2C 8X4\%2C and Hansaplast. (accessed May 16, 2021).

[2] ISACA, A Business Framework for the Governance and Management of Enterprise IT. ISACA, 2012.

[3] A. Hakim, H. Saragih, and A. Suharto, "Evaluasi Tata Kelola Teknologi Informasi Dengan Framework COBIT. 5 Di Kementerian ESDM,” J. Sist. Inf., vol. 10, no. 2, p. 105, Jan. 2015, Accessed: May 26, 2021. [Online]. Available: http://dx.doi.org/10.21609/jsi.v10i2.393.

[4] J. F. Andry, "Audit of IT Governance Based on COBIT 5 Assessments: A Case Study," J. Nas. Teknol. dan Sist. Inf., vol. 2, no. 2, pp. 27-34, Aug. 2016, Accessed: May 26, 2021. [Online]. Available: https://teknosi.fti.unand.ac.id/index.php/teknosi/article/view/45.

[5] S. Purwaningsih Sekolah Tinggi Ilmu Ekonomi Widya Manggala Jalan Sriwijaya, “Analisis Kesuksesan Penerapan Sistem Informasi pada Sistem Informasi Pelayanan Terpadu (SIPT) Online (Studi Pada PT Jamsostek (PERSERO))," 2010. Accessed: May 26, 2021. [Online]. Available: https://widyamanggala.ac.id/journal/index.php/jurnalaset/article/view/66.

[6] I. N. Rachmawati, "Pengumpulan Data Dalam Penelitian Kualitatif: Wawancara," J. Keperawatan Indones., vol. 11, no. 1, pp. 35-40, Mar. 2007, doi: 10.7454/jki.v11i1.184.

[7] K. A. Latief, "Populasi, Sample, dan Hypotesis," ar-raniry.ac.id, Jul. 2020, Accessed: Jul. 17, 2021. [Online]. Available: https://repository.ar-raniry.ac.id/id/eprint/14075/. 